\title{
Holistic Parenting Scale: Developing a Holistic Parenting Scale Model based on Islamic Values
}

\author{
Sri W Rahmawati ${ }^{1}$ \\ ${ }^{1}$ Faculty of Psychology, Universitas Tama Jagakarsa, Jakarta
}

*Correspondence to: Sri W Rahmawati, Faculty of Psychology, Universitas Tama Jagakarsa, Jakarta, Indonesia, E-mail:

\begin{abstract}
Islamic treasures have a parenting concept originating from the Holy Qur'an and the Hadith. I call this Islamic parenting concept a Holistic Parenting. Samples used in this study were as follows: five parents during the data elicitation stage, 228 male and female teenagers during the try-out stage and 616 16-to-17-year-old teenagers during the primary data collection stage. Based on the internal consistency test and construct validity test, the holistic parenting scale has a good validity and reliability. This scale is capable of measuring the same construct consistently, and is valid to measure the construct holistic parenting consisting of five dimensions namely: qudwah hasanah (integrated role model), al addah (habituation), al mauidzah (effective advice), al mulahadzah (fairness in care and control), and uqubah wa ujaroh (proportional consequences). Through the psychometric standard procedure that has been undergone, the holistic parenting scale presented in this study has been able to be employed to measure parents' parenting capability over their sons and daughters in the Muslim family in Indonesia.
\end{abstract}

Keywords: Scale, Parenting, Islamic Religious Based, Muslim Family

Article Received: 20 September 2020, Revised: 30 November 2020, Accepted: 18 December 2020

\section{Introduction}

Studies on parenting have so far put much stress on parenting styles widely known by developmental psychologists. Basically, parenting styles are classified into two big dimensions. The first dimension is control, demand, protection, supervision, or behavioral regulation (Lane, 2015) (Hughoghi, \& Long, 2004); moreover, the second dimension has something to do with warmness, involvement, attention, or acceptance. (Maccoby \& Martin on Santrock, 2018). Based on those two main dimension, four parenting styles that are combinations between the dimensions have been developed. There are four possible combinations, namely equally high on both, equally low on both, the first dimension is high while the second dimension is low, and the first dimension is low and the second dimension is high (Santrock, 2018; Spraitz, 2011) .

In general, basic parenting principles refer to the parenting styles based on those two main dimensions mentioned above (Spraitz, 2011). However, Islam with its universal teachings has its parenting concept based on the Holy Qur'an and the Hadith. (Ulwan, 2014). This parenting is prevailingly practiced by Indonesia's Muslim society, known as a religious society with traditions, cultures, and customs having been preserved for years (Rahmawati, 2016). Studies focusing on parenting based on religious values have not commonly been found. On the other hand, strengthened religious phenomena have also resulted in high parents' interests in learning the religion, including applying parenting techniques complying with the teachings of the Holy Qur'an and the Hadith in their sons' and daughters' parenting process.

Many ulemas (Muslim clerics) have written books on Islamic parenting known as tarbiyatul aulad. Of all existing tarbiyaul aulad concepts, the ideas of (Ulwan, 2014) are deemed by the majority of educators to be comprehensive ideas. Ulwan (2014) proposed five parenting methods that ulemas agreed upon as the best methods in the education. We call this Islamic parenting as holistic parenting. We have selected this term since holistic parenting has a comprehensive nature (Rahmawati, 2016). That parenting is holistic since it tries to combine practical parenting practices and religious values (in this case Islam). Moreover, this parenting has a 
holistic nature since not only does it place parenting as an effort to develop a psychological climate between the parents and the children, but it also integrates the formation of a psychological climate and the implementation of practical parenting principles simultaneously (Rahmawati, 2017a).

This study was aimed at formulating a valid and reliable holistic parenting scale that has good items. A holistic parenting scale with a good psychometric standard would give us advantages, so it would be of great benefits to know parenting methods applied by parents in Muslim families. Moreover, we could also employ this measuring instrument for studies in the fields of developmental psychology and educational psychology, especially concerning parenting.

In Islam, the importance of a child's education receives a big portion of attention as it is mentioned in the Holy Quran and the Hadith. Allah said, "O you who have believed, protect yourselves and your families from a Fire whose fuel is people and stones, over which are [appointed] angels, harsh and severe; they do not disobey Allah in what He commands them but do what they are commanded." (The Holy Qur'an, 66:6); The Prophet Muhammad said, "Teach your children and family virtues, and educate them (with virtues)" (Hadith narrated by At Thabrani, as referred to by Ulwan (2014).

Based on what is elaborated above, holistic parenting is defined as: "a comprehensive unity of parents' attitudes over and treatments of their children in educating, conditioning, and guiding their children in order that the children will be optimally developed under the religious bases (the Holy Qur'an and the Hadith)." Holistic parenting has a comprehensive cohesion, on matters as follows: (a) integrating the psychological atmosphere that is built and practical parenting practices. A psychological atmosphere here means a condition where the relationship between the parents and the children is nurtured, marked with warmness/affection; (b) holistic parenting elaborates Islamic parenting by applying practical steps, so it may give clear guidance to the educators; (c) holistic parenting makes Islamic elements as the parenting background in the Muslim families containing customs, rules, behavioral guidelines that parents apply to their children.

There are five dimensions in holistic parenting. Those dimensions are techniques in a parenting. They are: Qudwah hasanah (integrated role model), al adah (habituation), al mauidzah (effective advice), al mulahadzah (fairness in care and control), and uqubah wa ujaroh (proportional consequences)

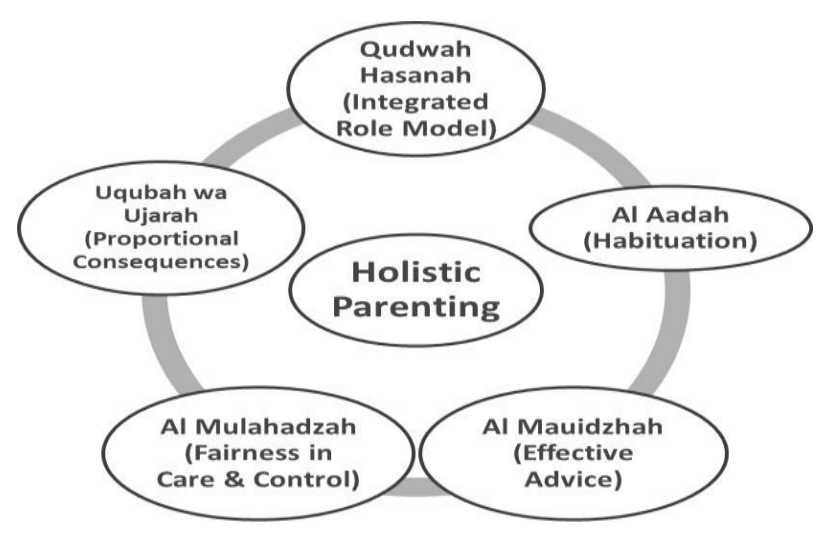

Figure 1. Holistic Parenting Techniques (Rahmawati, 2015)

Those holistic parenting techniques are sequential in their application. The first sequence in holistic parenting is qudwah hasanah (integrated role model); it is a parenting technique by becoming a role model to their children in their speeches, attitudes, and behaviors. This technique is based on the Holy Qur'an: “There has certainly been for you in the Messenger of Allah an excellent pattern for anyone whose hope is in Allah and the Last Day and [who] remembers Allah often." (Qur'an $33: 21$ ), and this following verse: "...O you who have believed, why do you say what you do not do? Great is hatred in the sight of Allah that you say what you do not do." (Qur'an 61:2-3). The next sequence is educating through a habituation (al addah), namely making a repeated habituation, so the child's behaviors will be developed in a purposeful manner This thing conforms to a Muslim cleric's advice: "if a child is accustomed to ugliness and is simply neglected, he or she will be miserable and hurt. Therefore, you should take care of your children by educating, disciplining, teaching them praiseworthy morals" (Imam 
Ghazali, as referred to by Ulwan, 2014). The third parenting technique is al mau'idzah (effective advice); it is educating children by way of giving them advice. When giving advice, it is necessary that you pay attention to any communication techniques, so the advice that you give will function effectively. This effective counseling technique is based on the Holy Qur'an: " $(\mathrm{O}$ Prophet), call to the way of your Lord with wisdom and goodly exhortation, 2 and reason with them in the best manner possible. 3 Surely your Lord knows best who has strayed away from His path, and He also knows well those who are guided to the Right Way." (Surah 16:125). Next, the fourth sequence is al mulahadzhah (fairness in care and control); it is an educational technique stressing on fairness in care and control in a balanced manner. The parents' attention will nurture an emotional closeness to the child, while control means monitoring the child in order that his or her behaviors will conform to the rules. This technique is based on a hadith. The Prophet Muhammad said, "Beware! Avoid sitting on he roads (ways)." The people said, "There is no way out of it as these are our sitting places where we have talks." The Prophet (- said, "If you must sit there, then observe the rights of the way." They asked, "What are the rights of the way?" He said, "They are the lowering of your gazes (on seeing what is illegal to look at), refraining from harming people, returning greetings, advocating good and forbidding evil.". (Hadith narrated by Bukhari and Muslim, as referred to by Ulwan, 2014). The fifth technique that is the last technique in the sequence of holistic parenting is uqubah wa ujarah (proportional consequences); it is educating by proportionally giving positive appreciation and consequences. These proportional consequences are a means of making the child obey the rules that have been approved together, so when the child violates a rule, the parents correct him or her by giving an appropriate consequence. This uqubah wa ujarah technique is based on a hadith. The Prohet Muhammad said, "What destroyed the nations preceding you (the Children of Israel), was that if a noble amongst them stole, they would forgive him, and if a poor person amongst them stole, they would inflict Allah's Legal punishment on him. By Allah, if Fatima, the daughter of Muhammad stole, I would cut off her hand". (Hadith Narrated by Bukhari and Muslim, as referred to by oleh Ulwan, 2014).

Below are the holistic parenting indicators employed in the formulation of the measuring instrument that have been summarized by the author based on the Holy Qur'an, the Hadith, and Ulwan's (2014) opinion:

Table 1. Holistic Parenting Indicators

\begin{tabular}{|c|c|c|}
\hline Technique & Definition & Indicator \\
\hline \multirow{3}{*}{$\begin{array}{c}\text { Qudwah } \\
\text { hasanah } \\
\text { (integrated role } \\
\text { model) }\end{array}$} & \multirow{3}{*}{$\begin{array}{l}\text { A parenting technique by becoming the } \\
\text { role model to the child; on the behaviors } \\
\text { both realized and unrealized; } \\
\text { accompanied with the harmony among } \\
\text { the words, attitudes and actions }\end{array}$} & $\begin{array}{l}\text { The parents become the child's } \\
\text { role model }\end{array}$ \\
\hline & & $\begin{array}{l}\text { Harmony among the words, } \\
\text { attitudes and actions }\end{array}$ \\
\hline & & $\begin{array}{l}\text { Automatically conducted } \\
\text { everyday }\end{array}$ \\
\hline \multirow[t]{2}{*}{$\begin{array}{c}\text { Al Addah } \\
\text { (habituation) }\end{array}$} & \multirow{2}{*}{$\begin{array}{l}\text { A parenting technique of enforcing the } \\
\text { discipline by way of exemplifying } \\
\text { positive/commendable behaviors and } \\
\text { avoiding despicable behaviors through }\end{array}$} & $\begin{array}{l}\text { Parents' enforcing the discipline } \\
\text { through habituation }\end{array}$ \\
\hline & & $\begin{array}{l}\text { The habituation is made } \\
\text { continually }\end{array}$ \\
\hline
\end{tabular}




\begin{tabular}{|c|c|c|}
\hline & $\begin{array}{l}\text { habituating the behaviors to the child } \\
\text { continually/sustainably and consistently }\end{array}$ & Consistent in the guidance time \\
\hline \multirow[t]{3}{*}{$\begin{array}{l}\text { Al Mau'idzah } \\
\text { (effective } \\
\text { advice) }\end{array}$} & \multirow{3}{*}{$\begin{array}{l}\text { A parenting technique by way of } \\
\text { delivering the wisdoms and lessons } \\
\text { gently and showing disapproval and } \\
\text { prohibition well and politely }\end{array}$} & $\begin{array}{l}\text { Employing appropriate words } \\
\text { (good, noble, impactful to the } \\
\text { listener) }\end{array}$ \\
\hline & & Employing various media \\
\hline & & Proper \\
\hline \multirow[t]{3}{*}{$\begin{array}{l}\text { Al Mulahadzah } \\
\text { (fairness in care } \\
\text { and control) }\end{array}$} & \multirow{3}{*}{$\begin{array}{l}\text { A parenting technique of parents' } \\
\text { giving attention and control to the child } \\
\text { in mental, physical, spiritual aspects } \\
\text { justly and gradually. Attention and } \\
\text { control are proportionally given, so } \\
\text { emotional closeness between the parents } \\
\text { and the child will be well nurtured. }\end{array}$} & $\begin{array}{l}\text { The available time that the } \\
\text { parents spend to give their } \\
\text { attention to their child is } \\
\text { sufficient }\end{array}$ \\
\hline & & $\begin{array}{l}\text { The available time that the } \\
\text { parents spend to control their } \\
\text { child is sufficient }\end{array}$ \\
\hline & & $\begin{array}{l}\text { Care and control are given to } \\
\text { various areas of guidance }\end{array}$ \\
\hline $\begin{array}{c}\text { Uqubah wa } \\
\text { Ujarah } \\
\text { (proportional } \\
\text { consequences) }\end{array}$ & $\begin{array}{l}\text { A parenting technique by way of giving } \\
\text { proportional consequences over the } \\
\text { child's actions, in order to maintain his } \\
\text { or her positive actions and, on the other } \\
\text { hand, to provide deterrent effect, so he } \\
\text { or she will not repeat his or her } \\
\text { negative actions. }\end{array}$ & $\begin{array}{l}\text { There are clear rules of the } \\
\text { game previously socialized to } \\
\text { the child before the parents give } \\
\text { any consequences. }\end{array}$ \\
\hline
\end{tabular}

\section{Method}

\section{Population, Sample and Sampling Techniques}

Population of this research is Muslim families in Indonesia. Samples of this study was Muslim families consisting of parents and 16-to-17-yearold teenagers. The sampling technique employed was a non-probability sampling since there were no similar opportunities for the individual who became population for the study's samples. The sampling process was conducted incidentally based on the participants' availability and willingness. The number of respondents that we manage to obtain during the elicitation period and the focus group discussion was five parents; for the purpose of data testing amounting to 228 teenagers, and for the purpose of primary data collection amounting to 616 male and female teenagers all of whom were Muslims. The parents' educational backgrounds were at the very least high school graduates, while the teenagers who became the participants were senior high school students.

\section{Research Design, Variables and Instrument}


The main approach employed in this study was a quantitative approach that was descriptive and with a non-experimental design. In the elicitation stage, the data mining started from the process of interviewing the parents; then, it continued with a focus group discussion to assess the holistic parenting techniques that the parents in those Muslim families applied. The next stage was trying out the measuring instrument conducted to the 16-to-17-year-old teenagers, and in the primary data collection that became the last stage, the respondents assessed their holistic parenting scale based on the parenting that they received in their families. After obtaining the data, we then made the analyses to see the overview of the formulated holistic parenting scale's validity and reliability.

\section{Model and Data Analysis}

The procedures for conducting the study started from the elicitation stage and focus group discussion to see how the theory suited the parenting techniques practices by the Muslim families in Indonesia. The elicitation started from interviewing 5 parents (three males and two females) whose ages ranged from 35 to 45 years old; it continued with a focus group discussion. The results of the elicitation and focus group discussion showed that all of the participants said that the holistic parenting techniques such as integrated role model (qudwah hasanah), habituation (al addah), effective advice (al mau'idzah), fairness in care and control (al mulahadzah), and proportional consequences (uqobah dan ujarah) were conducted by the parents in their parenting process to their children. After the elicitation and focus group discussion stage, we then formulated the indicators of each holistic parenting component and its sample item deemed to elaborate those indicators. After formulating the behavioral indicators of each component, we conducted an item pooling to collect items supposed to be able to represent each of the indicators. The next step was conducting a readability test on items formulated on three respondents who represented the samples' characteristics and on a psychometric expert. This readability test resulted in 67 items deemed to be able to measure holistic parenting, consisting of positive (favorable) and negative (unfavorable) items.

The items that had been obtained was randomly arranged for each of the indicators; then, they were tried out to 228 16-yo-17-year-old teenage respondents; 89 of them were males and 111 of them were females; all of them were Muslims. When filling out the try-out version holistic parenting scale, the respondents were asked to assess to what extent the statement that was displayed suited the description of their parents' parenting techniques applied to them, in Likert scale comprised of 1-6 ( from Strongly Disagree to Strongly Agree). Findings of the tryouts showed that the reliability of the holistic parenting measuring unit employing an alpha-cronbach technique amounted to $\alpha=0.947$. It meant that $94.7 \%$ of the variants came from the true score variants and $5.3 \%$ were variant's errors originating from the content sampling error and content heterogeneity error. In other words, items resulting from the tryouts of the holistic parenting measuring instrument could measure a similar construct. The correlation results of the total corrected items the value of which was below 0.3 were eliminated since they are deemed to be bad items (Kaplan \& Saccuzzo, 2009). After eliminating 15 bad items, we chose items that represented each of the behavioral indicators with the-best correlation values (over 0.3) and eliminated other 17 times the correlation values of which were slightly over 0.3 . In the end, the holistic parenting measuring instrument employed to collect the primary data consisted of 35 items with the Alpha Cronbach coefficient amounting to $\alpha=0.949$.

The holistic parenting scale consisting of 35 items and sourced from the initial data was tried out again to subjects with bigger numbers. We needed to do this since we wanted to select items deemed to be the most appropriate in representing the holistic parenting scale. Just like the respondents during the tryouts, when filling out the forms of holistic parenting scale, the respondents were asked to assess to what extent the statement that was displayed suited the description of their parents' parenting techniques applied to them, in Likert scale comprised of 1-6 ( from Strongly 
Disagree to Strongly Agree). The number of participants in this primary data collection was 616 16-to-17-year-old sons and daughters.

The analysis employed to examine the reliability of this holistic parenting measuring instrument was internal consistency through an alphacronbach coeficient (Kaplan \& Saccuzzo, 2009). This analysis technique was selected since this method could observe the consistency of the internal items of the holistic parenting measuring instrument when it measured the same construct. Moreover, the alpha-cronbach coefficient could be conducted in a single trial. The validity tests that were conducted were content validity and construct validity. The content validity was conducted through expert judgment. The construct validity was conducted through correlating the holistic parenting measurement instrument with another test named Baumrind's parenting style. A person who perceives a high level of his or her parents' holistic parenting will have a high value in democratic/authoritative parenting style deemed by developmental psychologists to be the most ideal parenting style (Hughoghi, \& Long, 2004; Spraitz, 2011; Mounts, 2002). On the other hand, a high score in the holistic parenting will have a negative score in an authoritarian parenting deemed by the experts as a parenting style not so ideal to be applied (Mounts, 2002; Krause, Pacey, \& Dailey, 2009). The holistic parenting measuring instrument were expected to significantly correlate with a democratic parenting style positively and to significantly correlate with an authoritarian parenting style negatively. In fact, measuring instrument of a democratic parenting style had a good inter-item consistency with the cronbach alpha coefficient amounting to $\alpha=0.833$, while the cronbach alpha coefficient of measuring instrument for an authoritarian parenting style amounted to $\alpha=0.898$.

Besides correlating with other tests, we also made a confirmatory factor analysis. This technique was employed to test the model of the holistic parenting measuring instrument that we were proposing and to identify whether those items that had been formulated had already described the holistic parenting components or factors based on
Ulwan's (2014) theory. Overall, the model compatibility test was observed from factor loading and other goodness of fit indexes such as chi-square, NNFI, NFI, CFI, IFI, AGFI, RFI, RMSEA, GFI, and so on. In this study, we made a second-order confirmatory factor analysis namely to test the model consisting of 35 items as observed indicators or variables, five components (qudwah hasanah-integrated role model, al addahhabituation, al mau'idzah-effective advice, al mulahadzah/fairness in care and control, and uqubah wa ujarah-proportional consequences) as the first-order latent variables and a second-order latent variable, namely holistic parenting, formed by those first-order latent variables.

We processed the data using SPSS for Windows 21.00 and Lisrel version 9.2. SPSS was used in the calculation process in order to obtain the alpha cronbach coefficient as an indicator of reliability, a correlation to calculate a construct validity, and a power item discrimination calculation (Field, 2009). Lisrel was employed to test the holistic parenting construct model hypothesized in this study (Vieira, 2012).

\section{Findings}

In the first stage, the psychometric test for the 67 items resulted in a reliability coefficient of the holistic parenting measuring instrument with $\alpha=0.904$. It meant that $90.4 \%$ of these measuring instrument variants were true variants and $9.6 \%$ were variant errors in the form of content sampling and content heterogeneity. The findings showed that 67 items of these holistic parenting measuring instrument had good reliability values. The validity used was a construct validity by correlating the total holistic parenting scores of those 67 items with the scores of democratic parenting and the authoritarian parenting style from Baumrind, and by making a confirmatory factor analysis. The correlation value of the holistic parenting for 46 items of the democratic parenting style that was obtained was $r=0.568(\mathrm{p}$ $<0.01$ ); it meant that there was a positive and significant correlation between the holistic parenting and the democratic parenting style. Meanwhile, the correlation score of holistic parenting for 67 items of the authoritarian 
parenting style resulted in the value amounting to $\mathrm{r}=-0.4(\mathrm{p}<0.01)$; it meant that there was a negative and significant between the holistic parenting and the authoritarian parenting style. The higher the holistic parenting that a person received, the lower the authoritarian he or she perceived.

The confirmatory factor analysis model deemed to be fit had several criteria such as: the value of X2 had to be lower than $\mathrm{p}>0.05$ and the model goodness of fit of CFI, NNFI, RFI, IFI, GFI, AGFI, and NFI were > 0.90 (Ghozali \& Fuad, 2014). The calculation results of confirmatory factor analysis showed that the initial holistic parenting model that was proposed consisted of five components as the latent variables and 46 items as the unfit observed variables $(\mathrm{X} 2=$ $2721.63(\mathrm{p}<0.01) ; \mathrm{RMSEA}=0.082, \mathrm{NNFI}=$ $0.86, \mathrm{CFI}=0.87$, IFI $=0.87)$. Items deemed to represent the factors well had at least the factor loading amounting to 0.3 . In the initial model with 67 items, there were 32 items with the loading factor below 0.3 and 35 items with the loading factor over 0.3. . We employed several stages when analyzing the items to determine which items had to be eliminated, revised, or maintained pursuant to the number of target items. Those three methods were by observing the cronbach's alpha if an item was deleted, and the corrected item-total correlation. Afterwards, we made an integrative analysis to select the best items in measuring the holistic parenting. The analysis that was made referred the previous item analysis; moreover, we also observed the factor loading based on the confirmatory factor analysis of each item. We selected the best 35 items deemed to be able to measure the holistic parenting concept.

The next stage was conducting the final psychometric test on those 35 selected items; we obtained the value of reliability coefficient amounting to $\alpha=0.8887$ based on the calculation result using a single trial (internal consistency).
Urbina (2004) stated that a measuring instrument would be deemed to be reliable if it had a coefficient amounting to 0.8 ; therefore, we could say that the calculation result above showed that the holistic parenting scale was reliable and had consistent items when they measured the same construct. Based on that coefficient it was also revealed that $88.87 \%$ of the respondents' holistic parenting values were obtained from the items in this measuring instrument, while the remaining $11.13 \%$ were the impacts of variant errors (content sampling and content heterogeneity). To make an analysis on to what extent the existing items could distinguish individuals with high holistic parenting from individuals with low holistic parenting, we also made the corrected item total correlation (cit) as a reference. We found out that of the 35 selected items, all of them had adequate corrected item total correlations (cit); the correlations ranged from $\mathrm{r}=0.3$ to $\mathrm{r}=0.6$. Therefore, this fact indicated that those thirty five items of the holistic parenting scale that we formulated were capable of distinguishing a person's level of holistic parenting scale from another's.

\section{Model fit}

We made a second-order model test of the confirmatory factor analysis consisting of 35 items as the observed indicators or variables, five components as the first-order latent variables (qudwah hasanah-integrated role model, al addahhabituation, al mau'idzah-effective advice, al mulahadzah-fairness in care and control, and uqubah wa ujarah-proportional consequences), and one second-order latent variable, namely holistic parenting, formed by those first-order latent variables. The calculation result of this model's confirmatory factor analysis showed that the data with the initial holistic parenting mode generated the goodness of fit as follows:

Table 2. Goodness of fit of the initial 35-item Holistic Parenting

\begin{tabular}{cccccccccc}
\hline$\chi^{2}$ & P & NFI & NNFI & CFI & IFI & RFI & RMSEA & GFI & AGFI \\
\hline 1263.01 & 0.00 & 0.89 & 0.93 & 0.94 & 0.94 & 0.89 & 0.075 & 0.76 & 0.73 \\
\hline
\end{tabular}


All of the items in the initial model already had a factor loading over 0.3 ; therefore, it could be concluded that the model was fitter than that of the 67-item holistic parenting. However, these testing results did not achieve a good goodness of fit. We then made a model re-specification by adding an error covariance based on modification indices. By adding an error covariance, the value of chi-square decreased for around 300 points. The table below showed the results of model respecification:

Table 3. Goodness of fit of the 35 -item Holistic Parenting after the model re-specification

\begin{tabular}{cccccccccc}
\hline$\chi^{2}$ & P & NFI & NNFI & CFI & IFI & RFI & RMSEA & GFI & AGFI \\
\hline 694.58 & 0.0 & 0.89 & 0.94 & 0.95 & 0.95 & 0.88 & 0.056 & 0.85 & 0.82 \\
\hline
\end{tabular}

The table above showed that the last model had NNFI, CFI, IFI >0.90 and RMSEA $<0.08$ which meant good compatibility. NFI, RFI, GFI and AGFI showed a marginal fit, while $\chi^{2}$ and $\mathrm{P}$ had not shown good compatibility. However, in general, the model was already good enough if measured based on most of the indexes.

From the analysis results of the last model, we found out that the factor loadings for each item ranged from 0.48 to 1.11 . The total variants of the qudwah hasanah /integrated role model component, which could explain about holistic parenting, amounted to $74 \%$. The total variants of the al mau'idzah-effective advice component amounted to $73 \%$. The total variants of al mulahadzah/fairness in care and control component amounted to $77 \%$, and the total variants of uqubah wa ujarah-proportional consequences amounted to $107 \%$. The calculation result of the measurement model reliability achieved a reliability construct value (CR) amounting to 0.97 and varians extracted (VE) amounting to 0.93. Ghozali \& Fuad (2014) and Vieira (2012) stated that the minimum value of good CR was 0.7, and the minimum value of good VE was 0.5. Based on this reference, the measurement model of this holistic parenting measurement instrument already had a good reliability. Moreover, we could see the final items and the amount of the loading factor of each item of the last confirmatory analysis test model from the table below:

Table 4. Holistic parenting scale items and their factor loading values

\begin{tabular}{|c|c|c|c|c|c|}
\hline Item & $\mathbf{R M}$ & HB & EA & $\mathbf{C C}$ & $\begin{array}{c}\mathrm{CO} \\
\mathbf{N}\end{array}$ \\
\hline $\begin{array}{l}\text { What my parents advised to me is not necessarily } \\
\text { applied by them * }\end{array}$ & 0.56 & & & & \\
\hline $\begin{array}{l}\text { All the advice given by my parents has been applied } \\
\text { in advance by them }\end{array}$ & 0.52 & & & & \\
\hline $\begin{array}{l}\text { There are differences between my parents' words } \\
\text { and actions* }\end{array}$ & 0.79 & & & & \\
\hline $\begin{array}{l}\text { What my parents say when educating me is } \\
\text { consistent with their actions }\end{array}$ & 0.69 & & & & \\
\hline My parents' words contradict their deeds* & 0.67 & & & & \\
\hline My parents tell the truth & 0.62 & & & & \\
\hline My parent lie to me* & 0.53 & & & & \\
\hline My parents' words are consistent with their deeds & 0.69 & & & & \\
\hline My parents' actions are in accordance with their & 0.60 & & & & \\
\hline
\end{tabular}




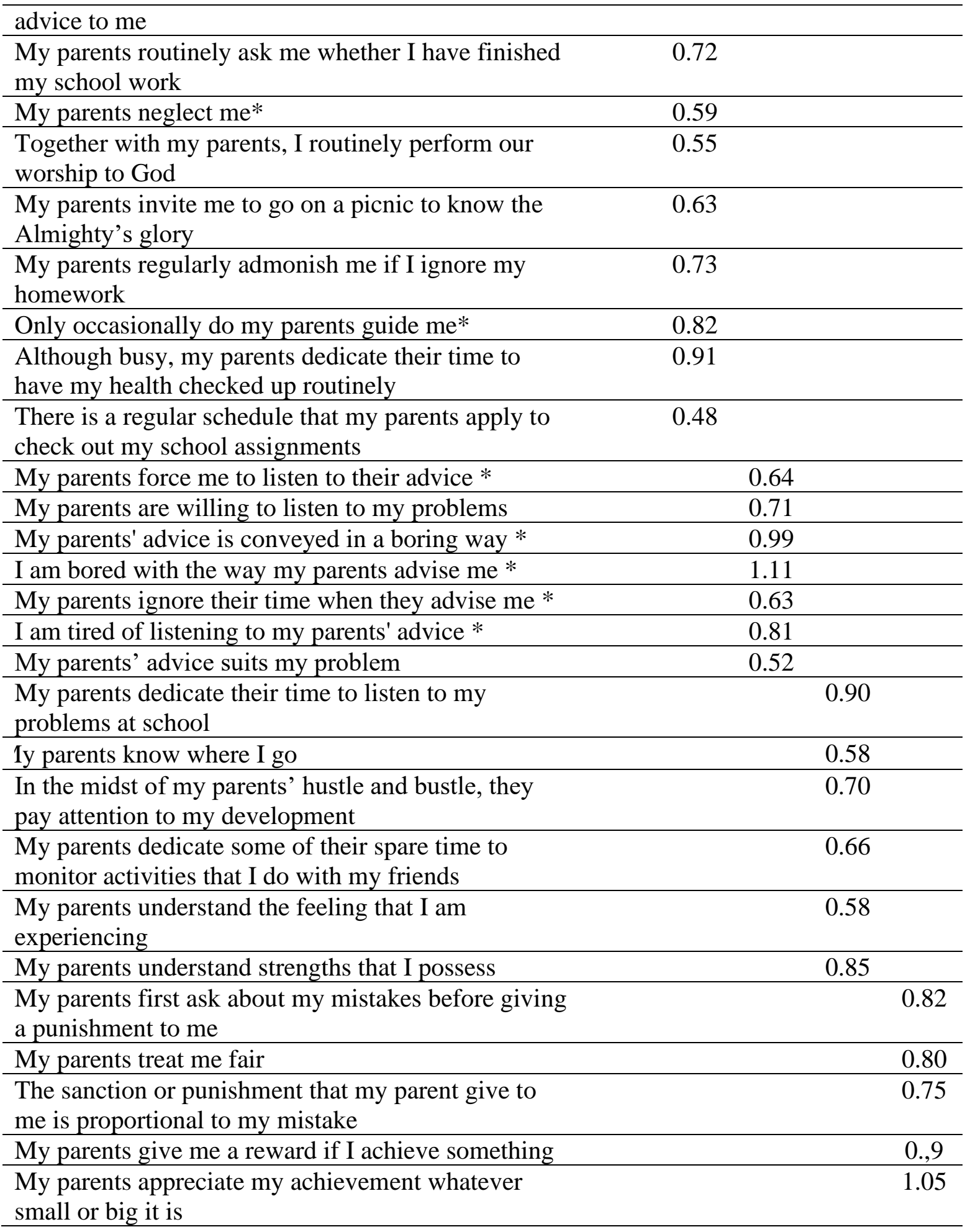

Information:

*item unfavorable, RM= integrated role model's factor loading, Hb=habituation's factor loading, $E A=$ effective advice's factor loading, CC=fairness in care and control's factor loading, Con= proportional consequences' factor loading

Based on the confirmatory factor analysis test, we found out that those five factors in theholistic parenting scale, namely: 1) qudwah hasanahintegrated role model/RM, (2) al addah-
habituation/HAB, (3) al mau'idzah-effective advice/EA, (4) al mulahadzah/fairness in care and control/CC, and (5) uqubah wa ujarahproportional consequences/CON, were capable of 
explaining the holistic parenting variants comprehensively in one factor. Therefore, we could say that the holistic parenting scale that was developed was uni-dimensional that could be measured using five components of the holistic parenting scale that was developed:

construct. The holistic parenting measuring instrument had a significant construct validity. The items found in the holistic parenting measuring instrument had good discriminating power, so they could distinguish a subject with high holistic parenting from a subject with low holistic parenting; Moreover, they had good goodnes fof on most of the required criteria.

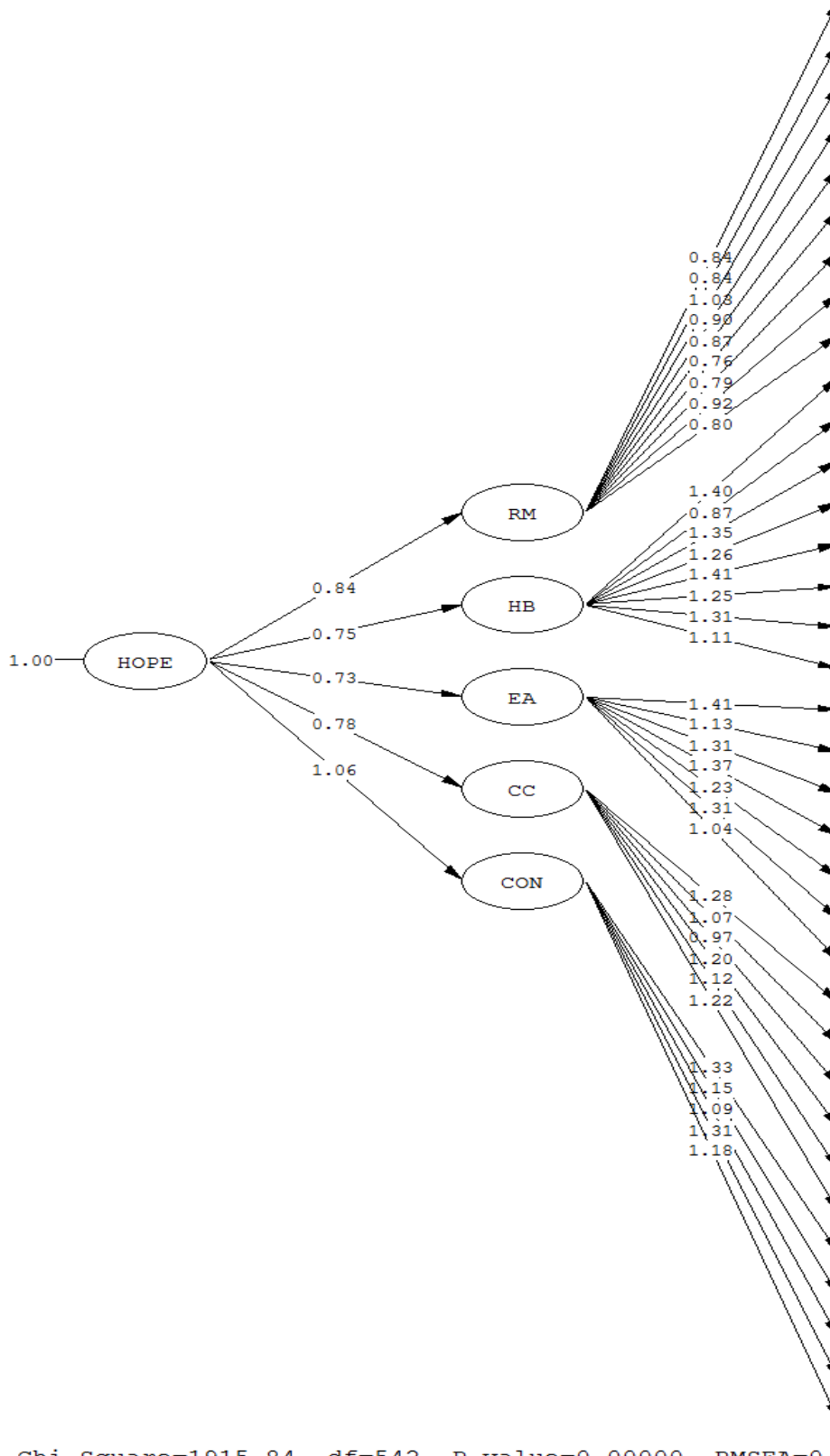

Chi-Square $=1915.84, \mathrm{df}=542, \mathrm{P}-\mathrm{value}=0.00000, \mathrm{RMSEA}=0$

\section{Figure 2. Final Holistic Parenting Scale Model}

Based on the analysis results and psychometric tests that had been conducted, we could draw some conclusion. The reliability tests that were obtained showed the holistic parenting measuring instrument's consistency in measuring one similar

\section{Discussions}

Holisstic parenting scale that we developed was psychometrie ally adequate. This holistic parenting scaleve vatidly' measured the holistic parenting construct año had a good internal consistency. Therefore $\vec{e},{ }^{\circ}$ that scale could be employed to 'meâsure TMús lim families' holistic parenting in Indônesia:

Based on the holistic parenting scale model test, we found $\vec{d}$ out, that there were five dimensions of the Mus lim families' holistic parenting construct These $\vec{h}^{\mathrm{IB}} \mathrm{I}^{12} \mathrm{istic}$ parenting dimensions were: - qudwah hasanah (integrated role model), al addah (habituation), al mauidzah (effective advice), al mutahadzah (fairness in care and control), and uqubah -0.1 wa ujaroh (proportional consecquences ((Rahmawati, 2017b); (Ulwan A.N, $201 \mathrm{Ft}) \cdot-0.07$

The Istamic okalues in each dimension are reflected on the parenting techniques that were employed, thatcosoriginated from the Holy Qur'an and the Hadith. For instance is the qudwah hasanah dimension. This dimension stresses on parenting through a role model. An educator must become a oleormoted $\circ$ the children with their positive behaviors: . This matter is based on the Holy Qurian. mo of surah Al Ahzab, verse 21, Allah Saidors "There has certainly been for you in the Messenger ${ }^{0}$ of Allah an excellent pattern for anyone whose hope is in Allah and the Last Day and [who] remembers Allah often". That it is important for the parents to be qudwah hasanah is consistent with a study conducted by McCoy (2015). In his study, McCoy says that it is important for the parents to directly educate their children on which behaviors are appropriate and inappropriate. Besides matters regarding values instilment, the parents are their children's role 
models in developing the children's psychological aspects such as language skills and the ability to appropriately express themselves in social situations (McCoy, 2015).

Another example is the al mauidzah dimension. It is a parenting technique emphasizing effective advice. This technique is based in a Quranic Verse. In Surah An Nahl, verse 125, Allah said, "Invite to the way of your Lord with wisdom and good instruction, and argue with them in a way that is best. Indeed, your Lord is most knowing of who has strayed from His way, and He is most knowing of who is [rightly] guided." (An Nahl:125). In this verse, An Nahl: 125, a mufassir named Ibnu Katsir explained that Allah Almighty ordered the Prophet Muhammad PBUH to invite people with wisdom, namely with various prohibitions and commands found in the Holy Qur'an. Allah Almighty also ordered the Prophet Muhammad PBUH to promote a dialogue softly, smoothly and in polite language. Allah also ordered the Prophet Musa PBUH and the Prophet Harun PBUH when they were sent to Fir'aun. Researchers in developmental psychology also emphasize the importance of the parents' communication skills in developing their child's positive behaviors. A communication appropriately delivered will make any advice, talks and discussion with the child able to be wellabsorbed by the child (Muth, 2012).

What distinguishes the holistic parenting scale construct from that of other previously existing parenting scales such as Baumrind's parenting scale (Power, 2016), and Muth's (Muth, 2012) parenting scale lies on the basic philosophy of the holistic parenting concept based on the Holy Qur'an and the Hadith. In Islam, parenting is one of the parents' main tasks that will be accounted for before Allah Almighty in their role as parents (The Holy Qur'an, Surah At Tahrim, Verse 6). Therefore, doing the parenting in accordance with to the ways guided in the Holy Qur'an and the Hadith is a form of humans' servitude to their Creator. In a parenting scale sourced from the western countries, the basic parenting philosophy only relies on parents' awareness of their role, without stating any God's roles in it. It seems that this thing is sourced from a secularism concept in the scientific perspective of the Western Countries, that separates religion from science. However, in Indonesia, separating God's roles in a religion from a psychologically personal area is not so relevant, especially taking into consideration that Indonesia makes a religious institution and theology its first national principle. Findings of the focus group discussion revealed that all of the respondents correlate one's task as a parent with his or her responsibility for Allah's mandate in the form of children in his or her family. Therefore, we think that this Indonesianversion holistic parenting scale becomes more representative when employed to measure parenting in Indonesia since it involves God's roles as a source in performing their responsibility as parents in the parenting.

Holistic parenting has parenting techniques consisting of five dimensions all of which are sourced from the Holy Qur'an and the Hadith. These holistic parenting techniques are applicative, so they give clear guidance to parents to apply them in the parenting. This is also what makes holistic parenting superior to Baumrind's parenting style (Spraitz, 2011), that tends to give a basic guide, but its use is not really practical to be applied by the parents, so they need to complete it with other more applicative parenting techniques (Spraitz, 2011; Muth, 2012; Power, 2016)

In addition to the benefits that it has generated, this holistic parenting scale still has some limitations. Holistic parenting scale has a good internal consistency using the alpha coefficient standard. The purpose of a reliability test with this technique is to find out the consistency among the items from a test, namely to what extent the items of that test consistently measure the same thing (Urbina, 2004). Therefore, this holistic parenting scale is capable of consistently measuring the same thing. However, we should keep in mind that when we use a consistency reliability test, we only measure the degree of the measuring instrument's reliability based on an internal criteria, namely the measuring instrument itself. We need to conduct a further test by using other reliability tests, especially test-retest to observe to what extent a participant is able to give a consistent response to the measurement of that 
holistic parenting at different times. The construct validity test that we used to see the compatibility of the holistic parenting construct with several external criteria employing other scales indicated any correlation between holistic parenting and other constructs. We found out that the higher a holistic parenting was, the higher a parenting measured using Baumrind's authoritative style, that was deemed to be an ideal parenting style. On the other hand, the lower a holistic parenting was, the lower an authoritarian style would be. Moreover, a construct validity test that also employed a self-report method could be further explored since it was very possible that personal subjective biases affected the emerging correlation. For further studies, we might consider employing more objective external criteria, such as a closest friend's report or a direct observation result of how holistic parenting was applied.

The results of confirmatory factor analysis revealed that the existing holistic parenting scale showed good model goodness of fit based on most of the indexes, namely NNFI, CFI, and IFI >0.9: RMESEA $<0.8$ (Ghozali \& Fuad, 2014). All of the holistic parenting scale items also has considerably good factor loading $(>0.3)$ to each of its components. However, there were still other unsatisfactory indexes; NFI, RFI, GFI and AGFI were still in the level of marginal fit, while $\chi 2$ and $\mathrm{P}$ had not shown good compatibility. Although the samples used in the final stage was quite adequate $(\mathrm{N}>500)$, considering many analysis items, we suggested doing the retest on more and more representative samples, using a probability sampling technique, so we would be able to employ an exploratory factor analysis. Through this exploratory factor analysis, we would find the number of factors deemed to be the most compatible for the items that were involved, so we would find the best model goodness of fit.

In relation to developing a scale that we might conduct, we are currently developing a teenagerversion holistic parenting scale. It is about how a teenager assesses his or her parents' holistic parenting. In the future, we need to develop a simpler version that may be used by younger children such as elementary school students with a modified language. Moreover, it is necessary for us to design a holistic parenting from the parents' perspective, so it will be able to measure parenting form the parents' point of view as an actor.

\section{Conclusion and Implication}

As an initial study in developing a parenting scale, this holistic parenting scale is deemed to have a good psychometric standard. It is found out that the holistic parenting scale has adequate construct and factorial validity. Moreover, it also has a good internal consistency. This Indonesian-version holistic parenting scale is also capable of measuring the same construct consistently, of distinguishing a person with a high holistic parenting from a person with a low holistic parenting, and is valid enough to measure the holistic parenting constructs through five factors, namely qudwah hasanah (integrated role model), al addah (habituation), al mauidzah (effective advice), al mulahadzah (fairness in care and control), and uqubah wa ujaroh (proportional consequences).

We should create a parent's version of this holistic parenting scale -besides a child's version that has been created- since parents are those taking the parenting role. Therefore, it may be used by parents from various backgrounds. In the case of those various backgrounds, methodically, we should revise the language, so it will be understood by all users, both by parents from various educational backgrounds or social economic statuses and by younger children or teenagers. By selecting more various participants, we hope that they may describe the spread of population age that is evenly distributed and may actually represent the target population.

\section{References}


[1] Field, A. (2009). Discovering statistics using SPSS (3rd ed.). London: Sage Publication.

[2] Ghozali, I., \& Fuad. (2014). Structural Equation Modelling. Teori, Konsep dan Aplikasi dengan Program Lisrel 9.10 (4th ed.). Semarang: Badan Penerbit Universitas Diponegoro.

[3] Hughoghi, M \& Long, N. (2004). Handbook of Parenting. Theory and Reserach for Practice. London: Sage Publication.

[4] Kaplan, R. M., \& Saccuzzo, D. P. (2009). Psychological testing (7th ed.). Belmont, CA: Wadsworth Cengage Learning.

[5] Krause, Pacey H., Dailey, T. M. (2009). Handbook of Parenting: Styles, Stresses, and Strategies. New York. Nova Science Publishers, Inc.

[6] Lane, T. (2015). Impact of parents' religious background on parenting style and children's religiosity in the orthodox jewish community. Retrieved from https://search.proquest.com/docview/1716 383160 ? accountid $=17242$

[7] McCoy, I. N. (2015). Parent as role model: A study of parent education and prosocial communication skills of children in northern virginia. https://doi.org/10.1073/pnas.040426210

[8] Mounts, N. S. (2002). Parental Management of Adolescent Peer Relationships in Context: The Role of Parenting Style, 16(1), 58-69. https://doi.org/10.1037//08933200.16.1.58

[9] Muth, T. J. (2012). Parenting and peer bullying: Parents' and adolescents' beliefs, communication, behavior and strategies. Ottawa: Published Heritage Branch, Inc.

[10] Power, T. G. (2016). Parenting Dimensions and Styles: A Brief History and Recommendations for Future Research. Childhood Obesity, 9(s1), S-14-
S-21.

https://doi.org/10.1089/chi.2013.0034

[11] Rahmawati, S. W. (2016). Holistic Parenting: Contribution Islamic Parenting in preventing school bullying in Jakarta, Indonesia. Journal of Education and Social Science, 5(2), 82-85. Retrieved from http://jesoc.com/wpcontent/uploads/2016/12/KC5_37.pdf

[12] Rahmawati, S. W. (2017a). Bullying siswa di sekolah menengah atas: Peran holistic parenting dan iklim sekolah terhadap bullying melalui variabel mediasi trait kepribadian lima besar. Bandung: Universitas Padjadjaran.

[13] Rahmawati, S. W. (2017b). Peran Pengasuhan Holistik Terhadap Altruisme dan Bullying. Humanitas Journal, 14(1), $10-25$.

https://doi.org/http://dx.doi.org/10.26555/h umanitas.v14i1.4316

[14] Ranjana, \& Rani, S. (2013). Parenting styles in relation to needs. Indian Journal of Health and Wellbeing, 4(5), 1206-1211. Retrieved from https://search.proquest.com/docview/1615 264236 ? accountid $=17242$

[15] Santrock, J. W. (2018). Life span development (17th ed.). New York: Mc Graw-Hill Education.

[16] Snider, J. B. (2002). The importance of parenting processes in the socialization of adolescents. Auburn University. Retrieved from

https://search.proquest.com/docview/3047 88672 ?accountid $=17242$

[17] Spraitz, J. D. (2011). Parenting styles and criminal involvement : a test of Baumrind , s typology. Indiana University of Pennsylvania.

[18] Ulwan A.N. (2014). Pendidikan Anak dalam Islam (Rahman, A.H., Terj.). Solo: Insan Kamil.

[19] Urbina, S. (2004). Essentials of psychological testing. New Jersey: John Wiley \& Sons, Inc. 
[20] Vieira, A. L. (2012). Interactive lisrel in practice. New York: Springer. Retrieved from http://www.springer.com/series/8921 